\title{
ADSORPTION/DESORPTION AND BIOFUNCTIONAL PROPERTIES OF OLEUROPEIN LOADED ON DIFFERENT TYPES OF SILK FIBROIN MATRICES
}

\author{
Oguz Bayraktar, ${ }^{1, *}$, Ali Bora Balta², Guldemet Basal Bayraktar ${ }^{3}$ \\ ${ }^{1}$ Department of Chemical Engineering, Ege University, Bornova-Izmir, Turkey \\ ${ }^{2}$ Department of Biotechnology, Izmir Institute of Technology, Urla-Izmir, Turkey \\ ${ }^{3}$ Department of Textile Engineering, Ege University, Bornova-Izmir, Turkey \\ oguz.bayraktar@ege.edu.tr; oguzbayraktar70@gmail.com
}

The objective of this study was to investigate the adsorption/desorption behavior of oleuropein on different types of silk fibroin matrices including silk fibroin microfibers (MF), regenerated silk fibroin (RSF), and silk fibroin nanofibers (NF). Nanofibers with an average diameter of ranging between 24 and $326 \mathrm{~nm}$ were successfully prepared using the electrospinning technique. The effects of the silk fibroin concentration, the voltage applied and the distance between needle tip and collector plate on the morphology of the NF were investigated. The adsorption capacities of MF, RSF and NF were determined as $104.92,163.07$ and $228.34 \mathrm{mg}$ oleuropein per gram of material, respectively. The percentage of initially adsorbed oleuropein that was desorbed was 86.08, 91.29 and $96.67 \%$ for MF, RSF and NF, respectively.

$\mathrm{NF}$ and RSF discs loaded with oleuropein were subjected to disc diffusion assays to determine their antibacterial activity against test microorganisms Staphylococcus epidermidis $($ Gram +$)$ and Escherichia coli $($ Gram - ). The results showed that both biomaterials possessed antibacterial properties after loading with oleuropein. Wound scratch assays using oleuropein released from NF revealed an enhancement of cell migration, indicating a wound healing property of the material.

In conclusion, the NF can be utilized as a biofunctional polymeric material with better performance for the adsorption and desorption of oleuropein compared with MF and RSF.

Keywords: nanofibers; silk fibroin; electrospinning; oleuropein; bioactivity

\section{АТСОРПЦИЈА/ДЕСОРПИЦИЈА И БИОФУНКЦИОНАЛНИ КАРАКТЕРИСТИКИ НА ОЛЕУРОПЕИН НАНЕСЕН НА РАЗЛИЧНИ ТИПОВИ МАТРИЦИ ОД СВИЛЕН ФИБРОИН}

Целта на ова истражување беше да се испитаат атсорпционите/десорпционите својства на олеуропеин нанесен на различни типови матрици од свилен фиброин: фиброински микровлакна $(\mathrm{MF})$, регенериран фиброин од свила (RSF) и нановлакна од фиброин од свила (NF). Со техниката за електрично предење успешно беа подготвени нановлакната со просечен пресек од 24 до $326 \mathrm{~nm}$. Беше испитано влијанието на концентрацијата на свилениот фиброин, применетиот напон и растојанието меѓу врвот на иглата и колекторската плоча врз морфологијата на NF. Беше утврдено дека атсорпционите капацитети на MF, RSF и NF изнесуваат, соодветно, 104,92, 163,07 и 228,34 $\mathrm{mg}$ олеуропеин на грам материјал. Процентот на иницијално атсорбиран олеуропеин што се десорбира изнесуваше соодветно, 86,08, 91,29 и 96,67\% за MF, RSF и NF.

Дисковите со NF и RSF со нанесен олеуропеин беа подложени на тестови со дифузија на дискот за да се определи нивната антибактериска активност за микроорганизми на Staphylococcus epidermidis $($ Gram +) и Escherichia coli (Gram - ). Резултатите покажаа дека двата материјала имаат антибактериски својства откако ќе им се додаде олеуропеин. Тестовите со третирање на рани од гребнатинки со употреба на олеуропеин ослободен од NF покажаа подобрување на миграцијата не клетките, што укажува дека материјалот има својство на лекување на рани.

Се заклучува дека NF може да се користи како биофункционален полимерен материјал кој има подобри својства за атсорпција и десорпција на олеуропеин во споредба со MF и RSF.

Клучни зборови: нановлакна; свилен фиброин; електрично предење; олеуропеин; биоактивност 


\section{INTRODUCTION}

Nanofibers have desirable properties such as interconnected ultra-fine pore structures, high surface area, and biodegradability and can show exceptional performance in biomedical applications $[1,2]$. In addition, they can be used in many industrial areas such as in medical textiles, in protective materials, in agriculture and in filtration [3, 4].

Nanofibers can be prepared using several techniques such as phase separation, melt-blowing, self-assembly, template synthesis and electrospinning. Among these techniques, electrospinning is usually preferred as it allows versatility in the control of the size of nanofibers, convenience for scaleup, and flexibility in terms of the materials used for nanofiber production [5]. Different biopolymers, such as collagen, silk fibroin, hyaluronic acid, and zein can be used to prepare nanofibers by electrospinning $[2,6,7]$. The silk fibroin used in this study is an important natural biopolymer and has been used to prepare electro-spun nanofibers that are used in many biotechnological applications such as in medical textiles, drug delivery and tissue scaffolding [8]. Besides its electrospinability, its biocompatibility and good mechanical and anti-inflammatory properties make silk fibroin a good candidate for tissue scaffold and wound dressing applications [5]. Silk fibroin has recently been used for the preparation of different forms of biomaterials for biotechnological applications as well [9-13]. It has also been investigated as a drug delivery carrier in the form of films, hydrogels, 3D matrices, and nanostructures. The available technologies for the development of silk based biomaterials, which can effectively deliver bioactive molecules including small drugs, proteins and genes, are well described in the literature [14]. These technologies for the preparation of drug delivery systems are based on a change in secondary structure of the silk fibroin from a random coil to a $\beta$-sheet form, allowing the control of drug release kinetics [15].

The antimicrobial properties of functional nanofibers that include antimicrobial agents such as silver ions have been reported in the literature $[16,17]$. However, less toxic, naturally occurring antimicrobial agents are still needed for biotechnological applications. Recently, nanofibers incorporating bioactive natural compounds have received much attention for biomedical and tissue engineering applications $[5,6]$. There is intense interest in the use of plant-derived natural compounds having different bioactivities for many biotechnological applications [18]. These natural compounds can be used in pharmaceutical preparations, cosmetic products, and food supplements due to their antioxidant, antimicrobial and anti-inflammatory properties [19]. Among them, oleuropein, the major component of olive leaf extract, has great potential for destroying microorganisms and free radicals that cause diseases and adverse effect on human health [20]. Therefore, incorporation of oleuropein as a bioactive natural compound into silk fibroin nanofibers was investigated in this study.

In the literature, most studies have focused on the characterization of silk fibroin based materials [21]. Recently, silk fibroin nanofibers have been evaluated in vitro and in vivo as potential biomaterials $[22,23]$. However, there are only a few articles in the literature about the incorporation of natural compounds into silk fibroin nanofibers [24, 25]. In several studies, nanofibers incorporating natural compounds have been prepared by electrospinning polymer blend solutions including natural compounds $[26,27]$. However, natural compounds have a tendency to lose their stability along with their bioactivities due to interactions with other components in blend solutions and under harsh conditions. Instead of directly mixing natural compounds into polymer solutions for electrospinning, it would be better to either prepare coaxial nanofibers encapsulating natural compounds in the core region [6], or to adsorb the natural compounds selectively on the surface of prepared nanofibers to avoid stability problems [5].

Adsorption can be considered as one of the best methods for incorporating oleuropein from olive leaf extract into silk fibroin nanofibers. Not only is this method efficient and convenient, but it is also applicable to small and large scale production of bioactive nanofibers. Several researchers have studied the potential applications of raw silk fibroin incorporating polyphenolic natural compounds [28]. In particular, the hydrophobic interactions between olive leaf polyphenols including oleuropein and silk fibroin have recently been examined [29], and very satisfactory results were obtained based on the amount of oleuropein adsorbed on the surface of silk fibroin fibers. Thus, the adsorption and desorption of oleuropein present in olive leaf extract (OLE) was investigated using silk fibroin nanofibers in the present study.

To the best of our knowledge, there is no article about the adsorption of oleuropein as a natural compound on to silk fibroin nanofibers. Therefore, in this study, different forms of silk fibroin structures including MF, RSF and NF were first prepared and were then compared based on their characteristics for the adsorption and desorption of oleuropein [5]. In addition, the wound healing and antibacterial properties of oleuropein on NF were studied using wound scratch and disc diffusion assays. 


\section{EXPERIMENTAL}

\subsection{Plant materials and chemicals}

Olive leaves (Olea europaea) were collected from trees in Urla-İzmir. In all extraction experiments, analytical grade ethanol $\left(\mathrm{C}_{2} \mathrm{H}_{5} \mathrm{OH}\right)$ was used and was purchased from Merck (Germany). Silk Fibroin (SF) was obtained in raw form from the Bursa Institute for Silkworm Research (Bursa, Turkey). In order to remove sericin, silk samples were boiled in sodium carbonate $(99.5+\%$ purity) solution purchased from Aldrich (Germany). Sodium sulfide hydrate provided by Fluka (Switzerland) and sulfuric acid (98+\% purity) from Merck (Germany) were used in the preparation of dialysis tubing (MW Cut-off: 12-14 kDa, Sigma (USA)). Calcium chloride-2-hydrate $\left(\mathrm{CaCl}_{2} \cdot 2 \mathrm{H}_{2} \mathrm{O}\right)$ was supplied by Riedel-de Haën (Germany) and used for the preparation of aqueous silk fibroin solution. Formic acid (98+\% purity) was purchased from Merck (Germany). HPLC grade acetonitrile from Sigma-Aldrich (Germany) and HPLC grade acetic acid from Merck (Germany) were used for the mobile phase of High Performance Liquid Chromatography (HPLC) analyses. The syringes and needles used in electrospinning experiments for the preparation of nanofibers were purchased from local medical suppliers. Ultrapure water was used in all experiments.

The methods used in this study can be divided into three main parts. The first part was the preparation and characterization of the olive leaf extract. The second part was the preparation of different forms of silk fibroin including MF, RSF and NF by degumming, freeze drying and electrospinning, respectively. The third part was the adsorption of olive leaf phenolic compounds on MF, RSF, and selected NF. Finally, desorption of olive leaf phenolic compounds from these different forms of silk fibroin materials was investigated.

\subsection{Preparation of crude olive leaf extracts [5]}

Fresh olive leaves were first washed with deionized water and then dried in an oven at $35^{\circ} \mathrm{C}$ (Memmert UFP 800TS) for three days. After grinding of the dried olive leaves with a grinder, extraction was performed in $70 \%$ aqueous ethanol solution with a solid-liquid ratio of 1:20 for 5 hours, at $180 \mathrm{rpm}$ and room temperature in a bench top orbital shaker (Thermo MaxQ-4000). The extract was vacuum-filtered and evaporated using a rotary evaporator (Heidolph laborata 4001) to remove the ethanol under vacuum at $35{ }^{\circ} \mathrm{C}$. The aqueous phase of the extract was centrifuged at $4000 \mathrm{rpm}$ for $5 \mathrm{~min}$ to remove solid residues. The liquid aqueous extracts were first frozen and then lyophilized using a Telstar cryodos-50 freeze drier for three days. After lyophilizate, dry crude extracts were obtained. The crude olive leaf extracts were stored in glass bottles in a dark, cool, dry place for use in further experiments.

\subsection{HPLC analysis of the prepared olive leaf extract}

An HPLC instrument (Hewlett-Packard Series HP 1100) with a diode array detector was used. A LiChrospher® RP-18 analytical column containing a silica gel carrier with $\mathrm{C}-18$ reversed phase properties $(250 \mathrm{~mm} \times 4 \mathrm{~mm}$ i.d.; particle size $5 \mathrm{~mm})$ and thermostated at $30^{\circ} \mathrm{C}$ was chosen as the stationary phase. The flow rate was $1 \mathrm{ml} \mathrm{min}^{-1}$ and absorbance changes were monitored at $280 \mathrm{~nm}$. For HPLC analysis, a previously reported method was used [29]. Briefly, the mobile phases for chromatographic analysis were: (A) acetic acid/water (2.5: 97.5) and (B) acetonitrile. A linear gradient was run from $95 \%$ (A) and $5 \%$ (B) to $75 \%$ (A) and $25 \%$ (B) over $20 \mathrm{~min}$; it was then changed to $50 \%(\mathrm{~A})$ and $50 \%$ (B) over $20 \mathrm{~min}$ (40 min, total time); then during the next $10 \mathrm{~min}$ it was changed to $20 \%$ (A) and $80 \%$ (B) (50 min, total time), with $10 \mathrm{~min}$ of reequilibration (60 min, total time) to return to the initial composition. Following the HPLC analysis, the concentration and abundance of oleuropein in the samples was determined based on a calibration curve of an oleuropein standard (purity $\geq 90 \%$, Extrasynthese, Genay Cedex, France).

\subsection{Preparation of silk fibroin microfibers $(M F)$ and aqueous silk fibroin solution}

Raw silk was boiled in an aqueous solution of $0.05 \%$ sodium carbonate (50 times $\mathrm{v} / \mathrm{w}$ ) for 30 min to remove the glue-like, sticky sericin surrounding fibroin fibers. This degumming process was repeated three times. The degummed silk was then washed several times with distilled water and left to dry under ambient conditions to obtain MF.

Aqueous silk fibroin solution was obtained by dissolving $1.2 \mathrm{~g} \mathrm{MF}$ in $20(\mathrm{v} / \mathrm{w}) \mathrm{CaCl}_{2} /$ distilled water/ethanol (molar ratio 1:8:2) by stirring at 78 ${ }^{\circ} \mathrm{C}$ for $2 \mathrm{~h}$, followed by dialysis at $4-8{ }^{\circ} \mathrm{C}$ for three days to remove neutral salts [30].

\subsection{Preparation of regenerated silk fibroin (RSF)}

Aqueous silk fibroin solution was filtered through filter paper and the collected solution was freeze-dried for five days in order to obtain completely dry material. At the end of this process, silk 
fibroin in the form of a foam was obtained and designated 'Regenerated Silk Fibroin (RSF)'.

\subsection{Preparation of silk fibroin nanofibers $(N F)$ by electrospinning}

A defined amount of RSF cut into small pieces was mixed with formic acid to obtain a silk fibroin polymer solution of the desired concentration. The polymer solution was stirred overnight and then stored for use in electrospinning experiments.

An electrospinning setup including a high voltage power supply (Iseg Spezialelektronik GmbH, Rossendorf, Germany), and a syringe pump (New Era Pump Systems NE300, USA) was used to prepare silk fibroin nanofibers.

A glass syringe with a needle of tip diameter $0.6 \mathrm{~mm}$ was filled with silk fibroin polymer solution and inserted into the syringe pump. The flow rate of the pump was adjusted to $6 \mathrm{ml} / \mathrm{h}$. The fibers were deposited on a constant target of aluminum foil at 17, 20 and $23 \mathrm{kV}$ using five different polymer concentrations $(60,80,100,120,150 \mathrm{mg} / \mathrm{ml})$. Two different distances between the needle tip and the target $(10$ and $15 \mathrm{~cm})$ were used for the electrospinning experiments.

\subsection{Characterization of silk fibroin fibers using scanning electron microscopy (SEM)}

Images recorded with a Scanning Electron Microscope (Philips XL 30S FEG and FEI Quanta FEG, Eindhoven, Holland) were used to observe the morphology of the fibers at the micro and nano scales. The samples were coated by gold sputtering in an argon atmosphere before SEM analysis. The average diameter of the fibers was determined by analyzing 100 randomly chosen fibers with ImageJ measurement and visualization software.

\subsection{Adsorption and desorption of oleuropein}

One of the most important parts of this study was the adsorption of olive leaf polyphenols onto the NF. MF and RSF were also used for adsorption studies. HPLC was used in all steps to determine the amount of adsorbed oleuropein. Finally, the oleuropein adsorption capacities of these three structures were compared and the results were expressed as $\mathrm{mg}$ oleuropein/g silk material.

First, the crude olive leaf extract was dissolved in ultra-pure water. The initial concentration $\left(\mathrm{C}_{\mathrm{i}}\right)$ of the extract solution was set as $100 \mathrm{mg}$ crude extract $/ \mathrm{ml}$ [5]. Before incorporating the extract into the silk fibroin materials (MF, RSF, NF), HPLC analysis of the crude extract was performed in order to determine the initial oleuropein content. Then, $1 \mathrm{~g}$ of silk fibroin material (MF, RSF, NF) was placed into $10 \mathrm{ml}\left(\mathrm{C}_{\mathrm{i}}=100 \mathrm{mg}\right.$ crude extract $/ \mathrm{ml}$ ) of extract solution. The silk fibroin material in the extract solution was shaken at $150 \mathrm{rpm}$, $25{ }^{\circ} \mathrm{C}$ for 5 hours. Every hour, a sample $(20 \mu \mathrm{l})$ was taken and analyzed by HPLC. Finally, using the data obtained over five hours and based on the HPLC chromatograms, the adsorbed amount of oleuropein was determined [5].

After adsorption, polyphenolic compound loaded silk fibroin materials (MF, RSF, NF) were obtained. First, silk fibroin materials were placed into $10 \mathrm{ml}$ water medium $\left(\mathrm{C}_{\mathrm{i}}=0 \mathrm{mg} / \mathrm{ml}\right)$ and shaken at $150 \mathrm{rpm}$ for 5 hours at $25^{\circ} \mathrm{C}$. Every hour, a sample $(20 \mu \mathrm{l})$ was taken and analyzed by HPLC. The data obtained over five hours were analyzed and, based on the HPLC chromatograms, the amount of desorbed oleuropein from the three structures was compared and the results were expressed as $\mathrm{mg}$ oleuropein/g silk material. All experiments were performed in triplicate.

\subsection{Antibacterial tests of regenerated silk fibroin $(R S F)$ and silk fibroin nanofibers (NF) loaded with oleuropein}

Cultured Staphylococcus epidermidis (Gram +) and Escherichia coli (Gram - ) bacteria were incubated in Petri dishes containing nutrient agar. Discs with a diameter of approximately $10 \mathrm{~mm}$ were cut from the RSF and NF materials. The discs were sterilized under UV light for 30 minutes before disc diffusion tests were performed. RSF and NF discs loaded with oleuropein were placed on the Petri dishes containing the bacterial cultures. After incubation at $37{ }^{\circ} \mathrm{C}$ overnight, inhibition zones around the discs and on the contacted surfaces were observed. In antibacterial tests, sterile discs with antibiotics including vancomycin (VA), gentamicin $(\mathrm{CN})$ and penicillin $(\mathrm{P})$ were used as positive controls. RSF and NF discs without oleuropein were prepared and used as negative controls. All experiments were carried out in duplicate.

\subsection{Wound scratch assays}

NIH-3T3 cells were grown in DMEM supplemented with $2 \mathrm{mM}$ L-glutamine, $10 \%$ fetal bovine serum (FBS), and $1 \%$ penicillin-streptomycin in an atmosphere of $5 \%$ carbon dioxide $\left(\mathrm{CO}_{2}\right)$ at $37^{\circ} \mathrm{C}$.

The effect of oleuropein desorbed from the $\mathrm{NF}$ into the medium during 5 hours of cell migration was determined using a wound scratch assay (scratching a straight line with a thickness of 800 $\mu \mathrm{m})$. Following incubation, the media was replaced with medium containing desorbed oleuro- 
pein from the NF. The closure of the cell-free region by cell migration was observed using a phase contrast inverted microscope after 24 hours. All experiments were carried out in duplicate.

\section{RESULTS AND DISCUSSION}

\subsection{Morphological characterization of nanofibers}

The morphologies of the electrospun NF were investigated using the SEM images presented in Figures 1 and 2. Each SEM image was scaled using ImageJ software to determine the average diameter of the fibers. Nanofibers were prepared using two different distances between the needle tip and the target $(10$ and $15 \mathrm{~cm})$, three distinct voltages $(17,20$ and $23 \mathrm{kV})$ and five silk fibroin concentrations $(60,80,100,120$ and $150 \mathrm{mg} / \mathrm{ml})$. The average diameters of the prepared nanofibers are shown in Table 1.

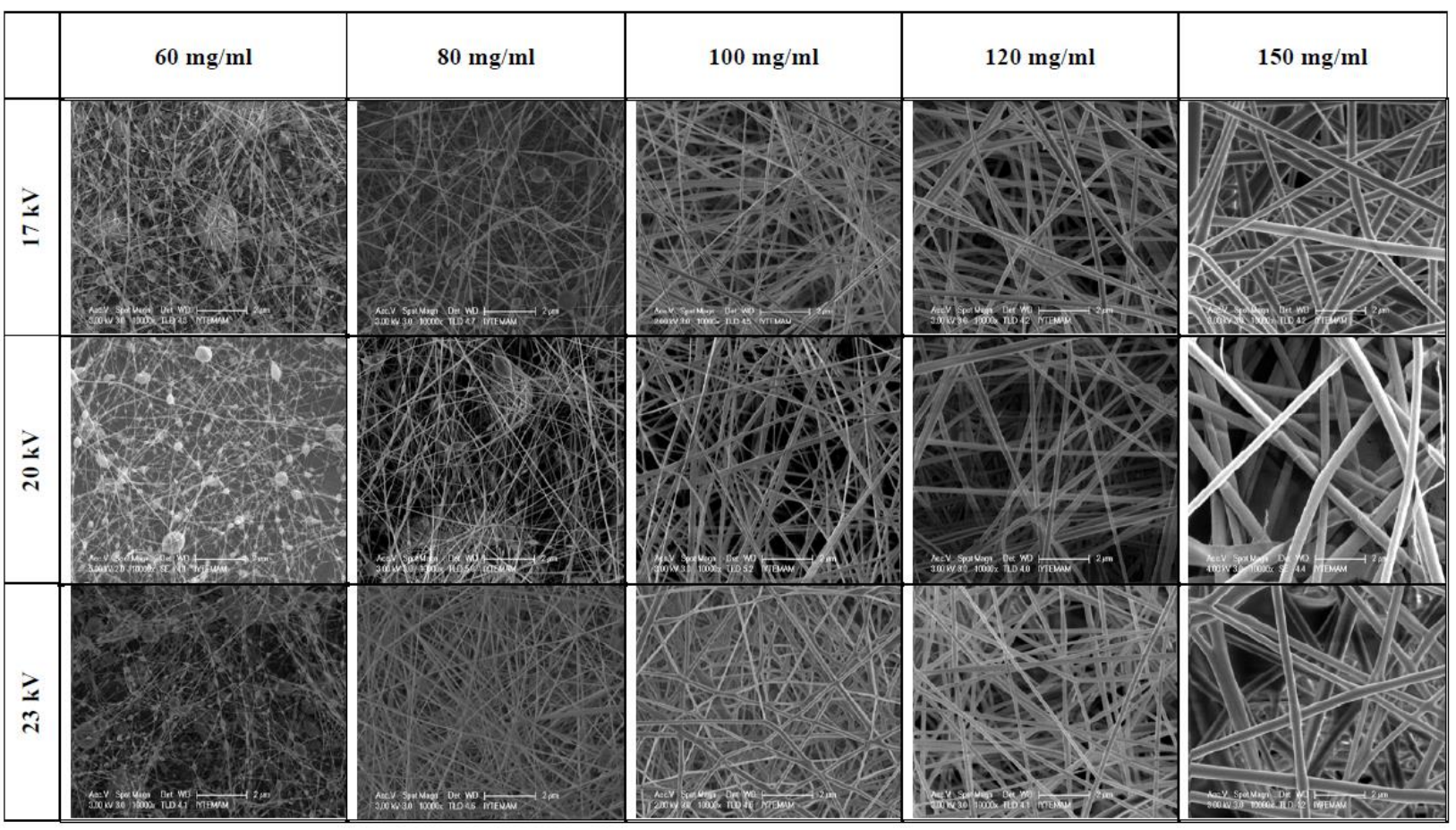

Fig. 1. SEM images of the prepared silk fibroin nanofibers under different electrospinning conditions with a constant distance of $10 \mathrm{~cm}$ between the tip and the collector plate

Table 1

The average diameters of prepared silk fibroin nanofibers under different electrospinning conditions

\begin{tabular}{ccccccc}
\hline \hline \multirow{2}{*}{$\begin{array}{c}\text { Distance } \\
(\mathbf{c m})\end{array}$} & $\begin{array}{c}\text { Voltage } \\
(\mathbf{k V})\end{array}$ & $\mathbf{6 0}$ & $\mathbf{8 0}$ & $\mathbf{1 0 0}$ & $\mathbf{1 2 0}$ & $\mathbf{1 5 0}$ \\
\cline { 3 - 7 } & $\mathbf{1 7}$ & 32 & 63 & 118 & 156 & 376 \\
$\mathbf{1 0}$ & $\mathbf{2 0}$ & 28 & 52 & 92 & 147 & 328 \\
& $\mathbf{2 3}$ & 26 & 45 & 85 & 140 & 318 \\
\hline \multirow{3}{*}{$\mathbf{1 5}$} & $\mathbf{1 7}$ & 28 & 45 & 95 & 123 & 294 \\
& $\mathbf{2 0}$ & 25 & 43 & 75 & 117 & 268 \\
& $\mathbf{2 3}$ & 24 & 40 & 73 & 115 & 264 \\
\hline \hline
\end{tabular}

Table 1 shows that the average diameter of the nanofibers varied between 24 to $376 \mathrm{~nm}$. By changing the parameters of the electrospinning process and the polymer solution, nanofibers with a wide range of sizes could be obtained. If the concentration of the silk fibroin polymer solution was increased, the average diameter of the nanofibers increased significantly. On the other hand, the average diameter of the nanofibers decreased with increasing distance between the syringe needle and the collector plate. Another important parameter affecting the size of the nanofibers was the applied voltage. When the voltage was increased, the diameter of nanofibers decreased to a certain degree.

On close examination of Figure 1, the effect of changing the silk fibroin polymer concentration on the diameter of fibers can be clearly seen at the relatively high silk fibroin concentration value of $120 \mathrm{mg} / \mathrm{ml}$. Also, there was an apparent increase in the size of the nanofibers at concentrations between 60 and $120 \mathrm{mg} / \mathrm{ml}$ with a significant change 
occurring at a silk fibroin concentration of 150 $\mathrm{mg} / \mathrm{ml}$.

A similar effect can be seen in Figure 2. The same electrospinning experiments were performed using a distance of $15 \mathrm{~cm}$ between the tip and the collector plate. Although the average diameter of the fibers decreased with increasing voltage, the effect of the applied voltage on the sizes of the nanofibers was not as significant as that of the silk fibroin concentration.

As seen in Figures 1 and 2, the morphology of the nanofibers varied as the electrospinning parameters were changed. Bead formation could clearly be seen in all nanofibers prepared using 60 $\mathrm{mg} / \mathrm{ml}$ silk fibroin solution at the different applied voltages and distances between tip and the collector plate. Electrospun nanofibers with beads have been commonly reported when the concentration of the solution or the molecular weight of the polymer used is low. Many studies in the literature have shown that low molecular weight/concentration/viscosity, high surface tension, and low charge density are the main factors contributing to bead formation [31]. By increasing the silk fibroin concentration in the electrospinning solution, bead formation was avoided and uniform nanofibers without beads were produced. The effect of the applied voltage on the morphology of the nanofibers can be observed in Figure 1. At a silk fibroin concentration of $80 \mathrm{mg} / \mathrm{ml}$ and an applied voltage of 17 or $20 \mathrm{kV}$, nanofibers still exhibited bead formation, but when the applied voltage was increased to $23 \mathrm{kV}$, the bead structures no longer formed, resulting in uniform nanofibers. In the literature, similar observations are also recorded for Nylon6 nanofibers prepared by electrospinning. Both the applied voltage and the distance were reported as effective parameters for controlling the diameter and size distribution of the Nylon6 nanofibers [32].

In our study, one set of nanofibers was chosen in order to investigate the adsorption capacity of nanofibers for the polyphenols from olive leaf extract. The nanofibers prepared with a polymer solution containing $100 \mathrm{mg} / \mathrm{ml}$ of silk fibroin electrospun at an applied voltage of $20 \mathrm{kV}$ and with a distance of $10 \mathrm{~cm}$ between the syringe needle and the collector plate were selected for further experiments. Under these electrospinning conditions, the prepared nanofibers were well separated from each other. Uniform nanofibers with a no-bead conformation were formed with a relatively small average size, and thus a higher external surface area for the adsorption of oleuropein. The expectation of better adsorption and desorption performance for nanofibers with a higher surface area led us to choose the nanofibers prepared under these electrospinning conditions for further use in adsorption/desorption, antimicrobial activity and wound healing studies.

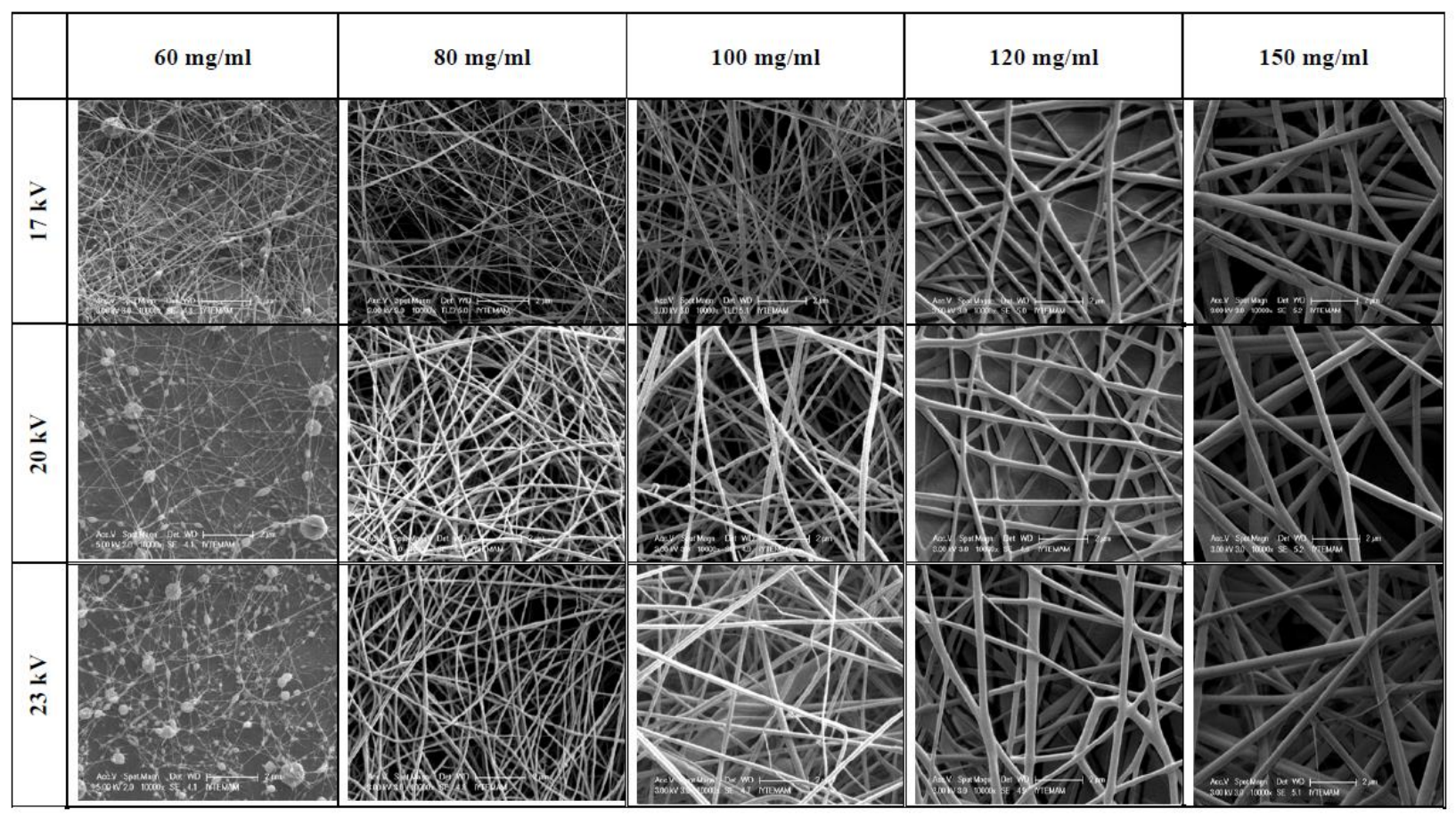

Fig. 2. SEM images of the prepared silk fibroin nanofibers under different electrospinning conditions with a constant distance of $15 \mathrm{~cm}$ between the tip and the collector plate. 


\subsection{Morphological characterization of silk fibroin $M F$ and $R S F$}

The morphology of the two different forms of silk fibroin (RSF and MF) was also investigated and compared with the silk fibroin nanofibers. In Figure 3, silk fibroin structures and their properties can be seen. The photo and the SEM image on the left in Figure 3 belong to MF obtained after degumming of raw silk material. The microfibers were then dissolved in $\mathrm{CaCl}_{2} \cdot 2 \mathrm{H}_{2} \mathrm{O} / \mathrm{EtOH} / \mathrm{H}_{2} \mathrm{O}$ solution to obtain an aqueous silk fibroin solution. After dialysis and freeze drying, RSF was prepared. This form presented a foam-like appearance as seen in the photograph and SEM image in the center of Figure 3. Finally, RSF was dissolved in formic acid to form a silk fibroin polymer solution, and NF was prepared by electrospinning. The photograph and SEM image on the right in Figure 3 show the silk fibroin nanofibers prepared with a polymer solution containing silk fibroin at $80 \mathrm{mg} / \mathrm{ml}$ with an applied voltage of $20 \mathrm{kV}$ and a distance of $10 \mathrm{~cm}$ between the syringe needle and the collector plate.

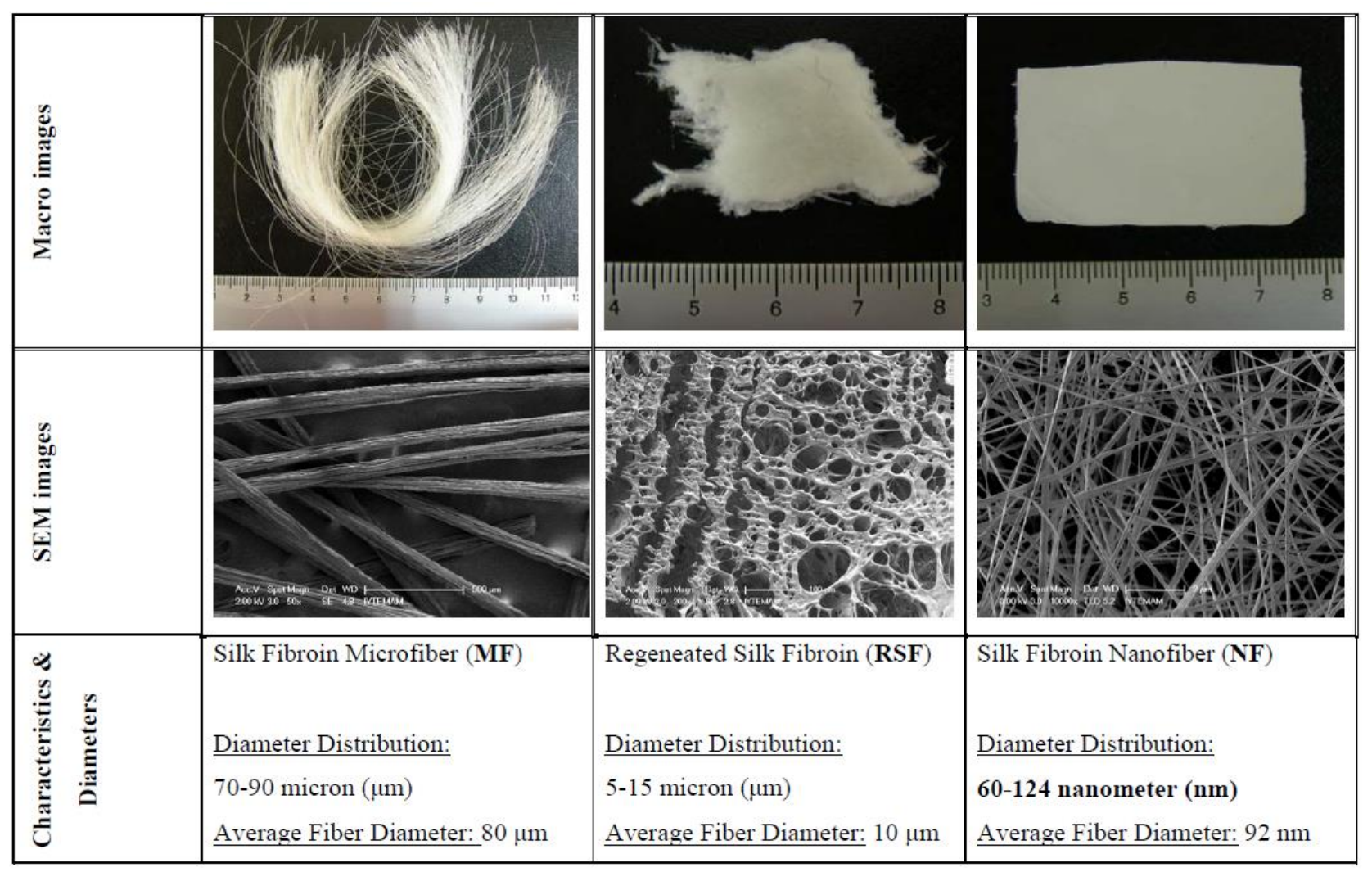

Fig. 3. Photographs and SEM images of silk fibroin microfibers (MF), regenerated silk fibroin (RSF) and nanofibers (NF)

In addition, adsorption of olive leaf polyphenols on these different forms of silk fibroin material was investigated. Olive leaf is rich in phenolic content and oleuropein (ole) is the most abundant compound in olive leaves. Therefore, HPLC analyses were performed in order to determine the adsorbed amount of oleuropein on different forms of silk fibroin materials. First, the initial concentration of oleuropein in the crude olive leaf extract was determined as $2.517 \mathrm{mg}$ oleuropein $/ \mathrm{ml}$. An HPLC chromatogram of the olive leaf extract can be seen in Figure 4. Oleuropein was detected as a major compound among other phenolic compounds eluted at 21 minutes.
Adsorption experiments were performed for each form of the silk fibroin materials. Their adsorption capacities are shown in Table 2. Initially there was no adsorbed oleuropein on the surfaces of the silk fibroin materials, therefore the initial oleuropein concentration was taken as zero $\left(C_{i}=0\right.$ $\mathrm{mg}$ oleuropein/g silk fibroin material). The results in Table 2 show that the NF had a higher adsorption capacity for oleuropein compared with MF and RSF. The adsorption capacities were determined as $104.92,163.07$, and $228.34 \mathrm{mg}$ oleuropein per gram of silk material for MF, RSF and $\mathrm{NF}$, respectively. 


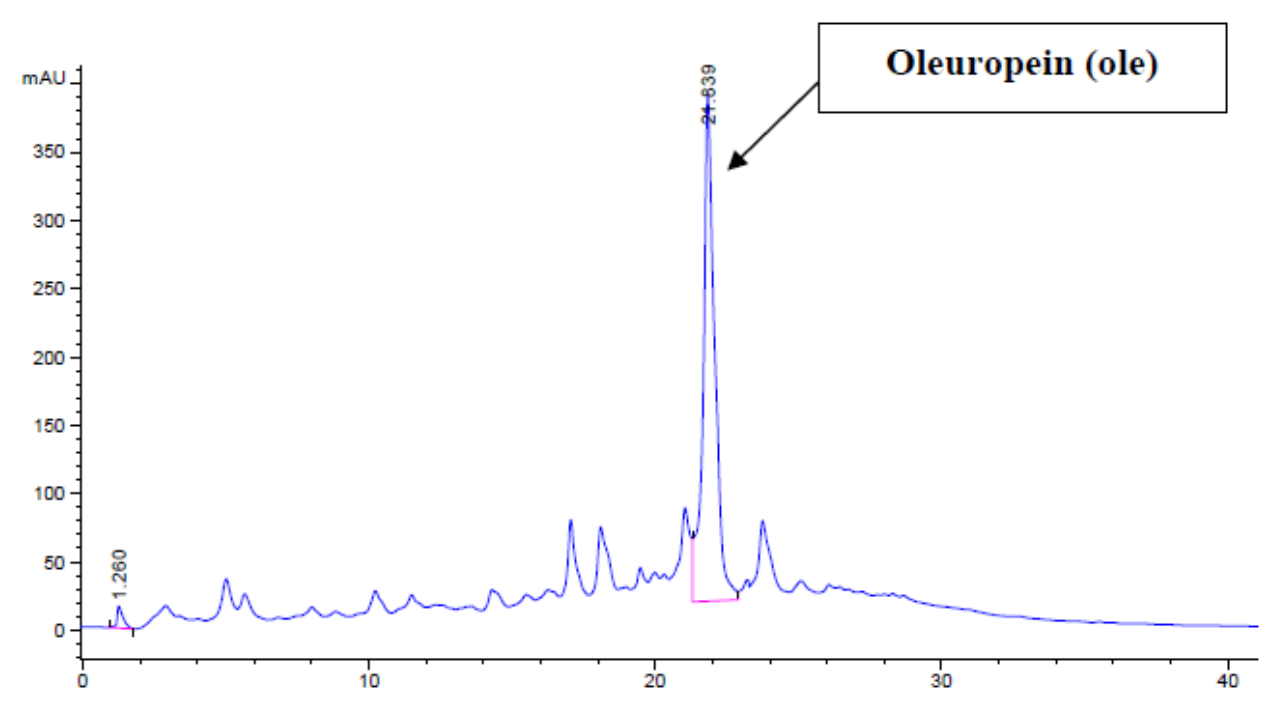

Fig. 4. HPLC chromatogram of olive leaf extract; Oleuropein (ole)

\section{Table 2}

The amounts of adsorbed oleuropein on the surface of the silk fibroin microfibers $(M F)$, regenerated silk fibroin (RSF) and nanofibers (NF) during

five hours of adsorption experiments

\begin{tabular}{cccc}
\hline \hline $\begin{array}{c}\text { Time } \\
\text { (minute) }\end{array}$ & $\begin{array}{c}\text { SF Microfiber } \\
\text { (mg ole/g MF) }\end{array}$ & $\begin{array}{c}\text { RSF } \\
\text { (mg ole/g RSF) }\end{array}$ & $\begin{array}{c}\text { SF Nanofiber } \\
\text { (mg ole/g NF) }\end{array}$ \\
\hline 0 & 0.00 & 0.00 & 0.00 \\
60 & 85.37 & 119.11 & 159.03 \\
120 & 96.51 & 142.70 & 205.40 \\
180 & 101.01 & 153.43 & 217.19 \\
240 & 103.06 & 160.51 & 222.54 \\
300 & 104.92 & 163.07 & 228.34 \\
\hline \hline
\end{tabular}

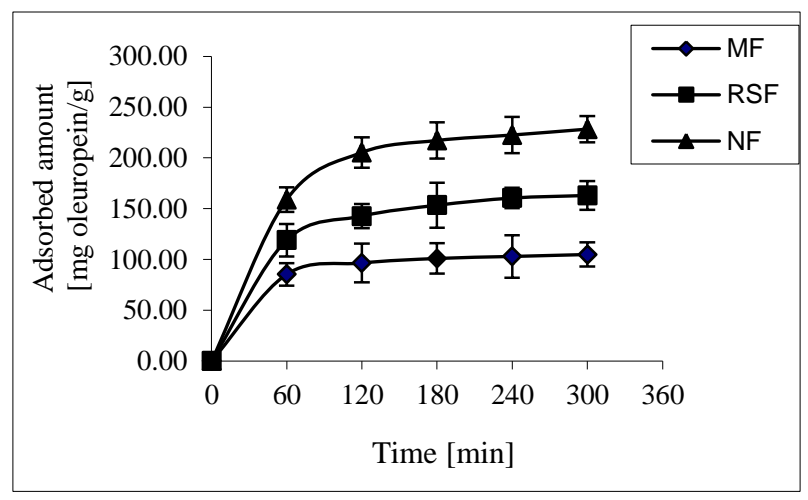

Fig. 5. Adsorption of oleuropein on silk fibroin microfibers (MF), regenerated silk fibroin (RSF) and nanofibers (NF) over a five-hour period

Figure 5 shows the adsorption profile of oleuropein on silk fibroin MF, RSF and NF. It can be clearly seen from the graph that silk fibroin nanofibers adsorbed the maximum amount of oleuropein. This can be attributed to the high sur- face area of the nanofibers. Silk fibroin nanofibers are known to have a high surface area compared with other forms of silk fibroin. As seen in the HPLC chromatograms (Fig. 6), the amount of oleuropein in the adsorption medium decreased due to its adsorption on the surface of silk fibroin materials at the end of the five-hour period, indicating that the adsorption process was rather efficient.

Desorption experiments were also performed for each form of the silk fibroin materials. As seen in Table 3, the initial oleuropein concentrations of the silk fibroin materials were different due to their different adsorption capacities. Therefore, the amounts of oleuropein adsorbed on the silk fibroin materials were taken as the initial concentrations for desorption experiments. During desorption, a sample was taken from the medium every hour and analyzed by HPLC. The initial concentration in the medium was taken as zero $\left(\mathrm{C}_{\mathrm{i}, \text { medium }}=0 \mathrm{mg}\right)$ due to absence of oleuropein at the start of the experiment. Using the amount of desorbed oleuropein determined by HPLC, the amount of oleuropein remaining on the silk fibroin material was calculated and recorded in Table 3. The amount of oleuropein on the silk fibroin MF decreased from 104.92 to $14.61 \mathrm{mg}$ oleuropein per gram of MF. However, the amount of oleuropein on the RSF decreased from 163.07 to $14.2 \mathrm{mg}$ oleuropein per gram. On the other hand, the amount of oleuropein on the silk fibroin NF decreased from 228.34 to $7.6 \mathrm{mg}$ oleuropein per gram. NF desorbed $96.67 \%$ of the initially adsorbed oleuropein, whereas MF and RSF desorbed only 86.08 and $91.29 \%$ of the initially adsorbed oleuropein, respectively (Figure 7). 


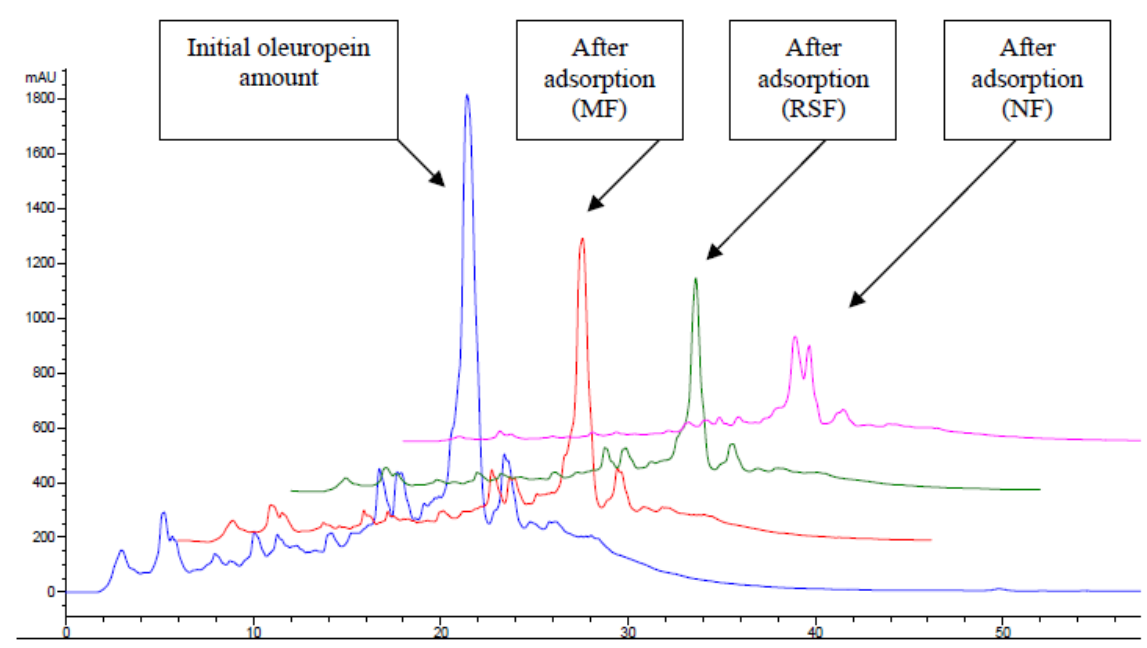

Fig. 6. HPLC chromatograms of initial adsorption medium and the medium after five-hour adsorption experiments with silk fibroin microfibers (MF), regenerated silk fibroin (RSF) and nanofibers (NF)

T a ble 3

The amount of oleuropein on the surface of silk fibroin microfibers $(M F)$, regenerated silk fibroin $(R S F)$ and nanofibers $(N F)$ during five-hour desorption experiments

\begin{tabular}{cccc}
\hline \hline $\begin{array}{c}\text { Time } \\
\text { (minute) }\end{array}$ & $\begin{array}{c}\text { SF Microfiber } \\
\text { (mg ole/g MF) }\end{array}$ & $\begin{array}{c}\text { RSF } \\
\text { (mg ole/g } \\
\text { RSF) }\end{array}$ & $\begin{array}{c}\text { SF Nanofiber } \\
\text { (mg ole/g NF) }\end{array}$ \\
\hline 0 & 104.92 & 163.07 & 228.34 \\
60 & 35.27 & 99.08 & 119.56 \\
120 & 17.97 & 57.81 & 70.52 \\
180 & 14.97 & 38.56 & 34.63 \\
240 & 14.85 & 22.57 & 10.41 \\
300 & 14.61 & 14.20 & 7.60 \\
\hline \hline
\end{tabular}

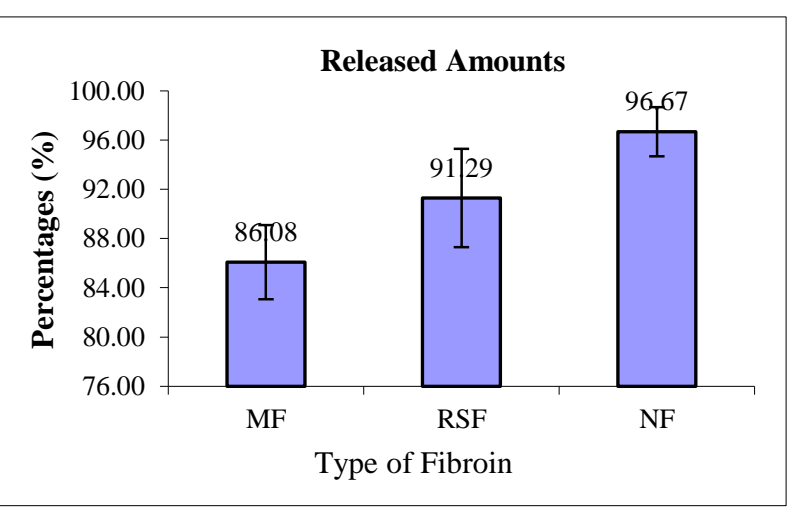

Fig. 7. Percentages of oleuropein desorbed into the medium from silk fibroin microfibers (MF), regenerated silk fibroin (RSF) and nanofibers (NF) after five hours

Figure 8 shows the desorption profiles of oleuropein for MF, RSF and NF. It can clearly be seen from the graph that NF desorbed the maximum amount of oleuropein, resulting in a lower amount of adsorbed oleuropein at the end of the five-hour desorption period. This can also be attributed to the high surface area of nanofibers. As seen in the HPLC chromatograms (Fig. 9), the amount of oleuropein in the desorption medium increased due to its desorption from the surface of the silk fibroin materials, indicating that the desorption as well as the adsorption was an efficient process.

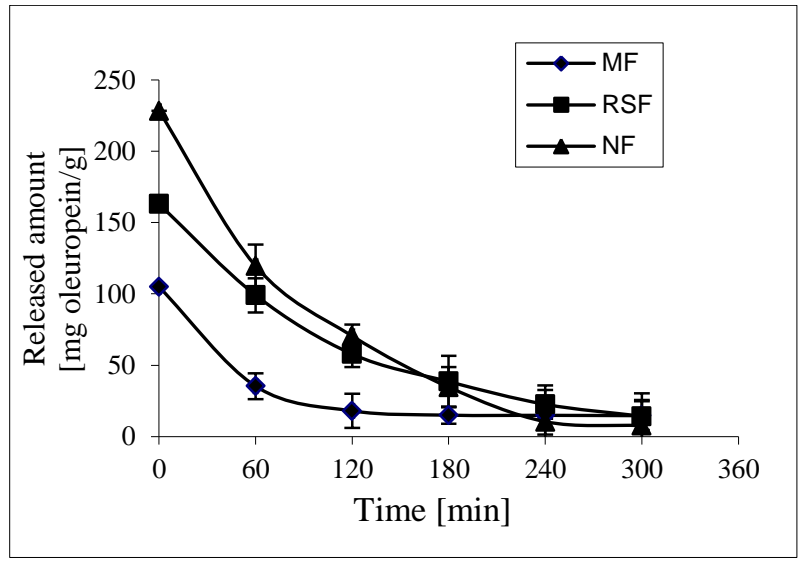

Fig. 8. Desorption of oleuropein from silk fibroin microfibers (MF), regenerated silk fibroin (RSF) and nanofibers (NF) over five hours

As can be seen from the HPLC chromatograms, MF, RSF and NF showed very satisfactory desorption profiles. The bioactive plant-derived compounds adsorbed on the nanofiber surfaces were effectively released into the medium. Therefore, these kinds of bio-functional nanofibers including bioactive plant compounds can be considered as potential candidates for novel medical applications. 


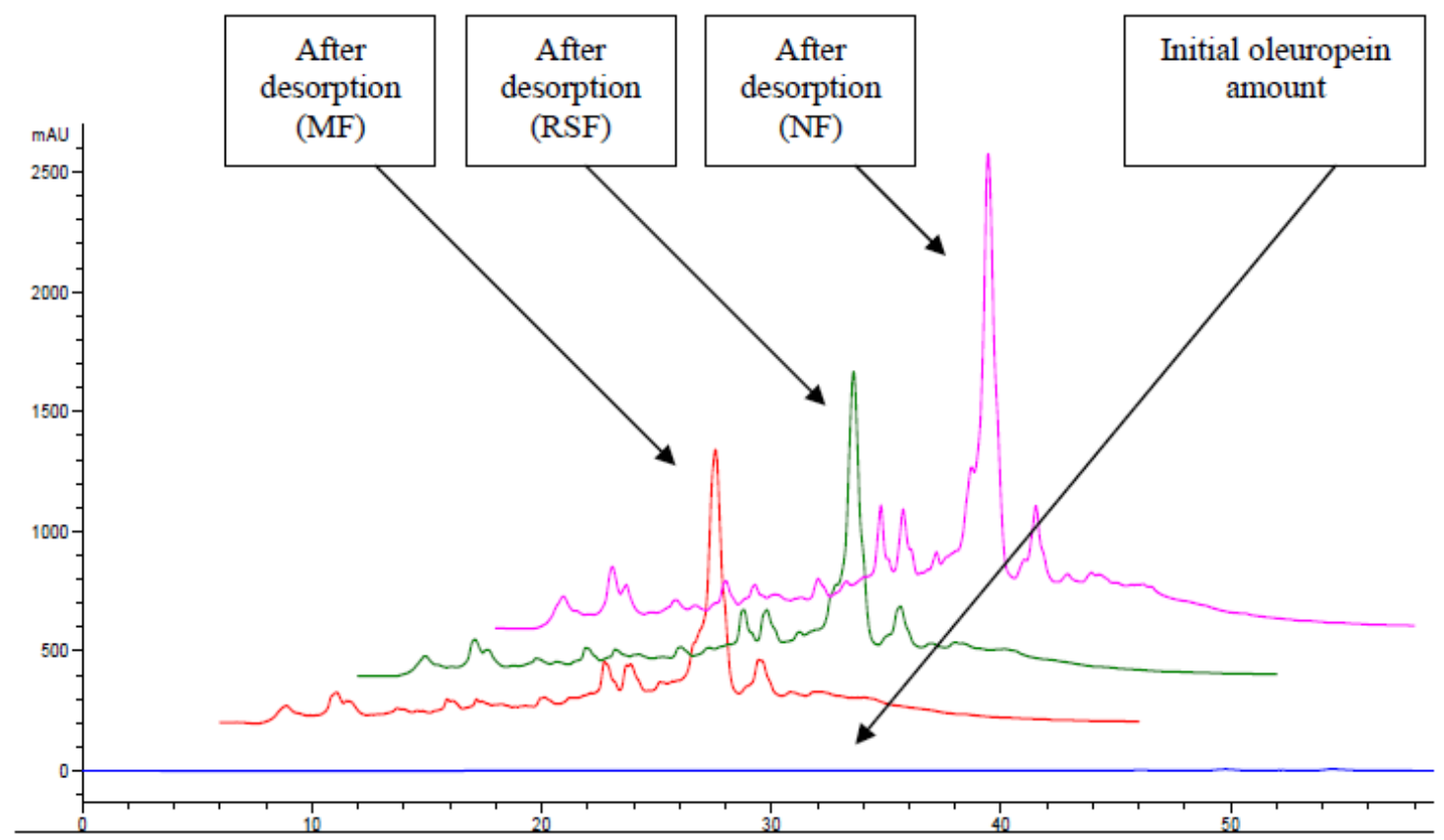

Fig. 9. HPLC chromatograms of the initial desorption medium and the medium after five-hour desorption experiments with silk fibroin microfibers (MF), regenerated silk fibroin (RSF) and nanofibers (NF)

In the literature, there are only a limited number of studies concerning the adsorption of polyphenols on silk fibroin. It was previously shown that olive leaf polyphenols can be adsorbed on unprocessed silk fibroin material [29]. The adsorption of polyphenols on silk fibroin was attributed to hydrophobic interactions and it was reported that $96 \mathrm{mg}$ of active compound per gram (oleuropein) could be adsorbed onto silk fibroin material. To the best of our knowledge, there is no previous article concerning the adsorption of oleuropein as a natural compound on silk fibroin nanofibers. The adsorption of oleuropein olive leaf extract onto silk fibroin nanofibers is very important because both silk fibroin and plant-derived bioactive components are natural. Therefore, their combinations are biocompatible and biodegradable. If these types of novel nanofibers containing natural compounds are used in wound healing materials, they should be able to adsorb and desorb their bioactive natural compounds effectively, as in the present study.

\subsection{Antibacterial tests and wound scratch assays}

In antibacterial tests, Gram-negative (E. coli) and Gram-positive (S. epidermidis) bacteria were used to determine the antibacterial properties of the materials. These bacteria are the most common isolates from chronic wounds. The cell wall in Gram positive bacteria consists of a single layer, whereas that in Gram negative bacteria consists of a multi-layered structure bounded by an outer cell membrane. This difference results in different levels of antimicrobial resistance. Therefore, antibacterial activities of the materials against $E$. coli and $S$. epidermidis, which represent Gram negative and Gram positive bacteria, were determined. Figure 10 shows the antibacterial test results of positive (+) and negative (-) controls for E. coli and S. epidermidis. The inhibition zones around discs containing gentamicin $(\mathrm{CN})$, vancomycin $(\mathrm{VA})$ and penicillin (P), can clearly be seen for both E. coli and $S$. epidermidis. The disc labeled as $\mathrm{C}$ is the control NF without oleuropein, which did not cause an inhibition zone for either species. This result is expected since there is no antibacterial agent (oleuropein) on the discs. The inhibition zones around NF and RSF discs loaded with oleuropein for the test microorganisms E. coli and $S$. epidermidis are shown in Figure 11. In both sides of the figure, the NF discs labeled A $(1.50 \mathrm{mg}$ oleuropein) and C (2.25 mg oleuropein) are loaded with lower and higher concentrations of oleuropein, respectively, while the RSF discs labeled B (2.90 $\mathrm{mg}$ oleuropein) and D (4.00 mg oleuropein) are loaded with lower and higher concentrations of oleuropein, respectively. Both NF and RSF discs loaded with oleuropein exhibited inhibition zones for both E. coli and S. epidermidis.

These results confirmed that the NF and RSF biomaterials possessed antibacterial properties after loading with oleuropein. 


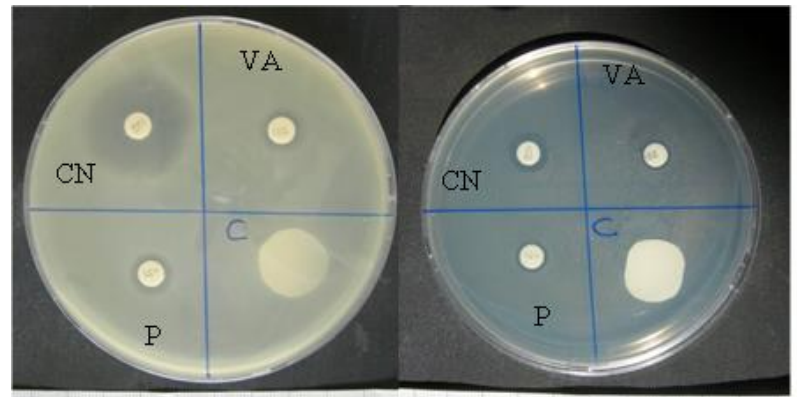

Fig. 10. Disc diffusion tests results for E. coli (left picture) and S. epidermidis (right picture): Sterile discs containing the antibiotics vancomycin (VA), gentamicin $(\mathrm{CN})$ and penicillin (P) used as $(+)$ control; NF disc without oleuropein used as $(-)$ control $(\mathrm{C})$.

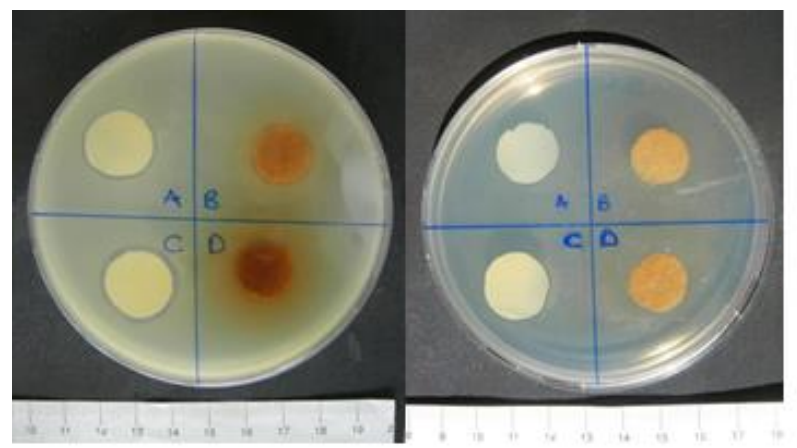

Fig. 11. Disc diffusion tests for E. coli (left picture) and $S$. epidermidis (right picture): NF discs labeled A and C are loaded with lower and higher concentrations of oleuropein, respectively. RSF discs labeled B and D are loaded with lower and higher concentrations of oleuropein, respectively.
In Figure 12, micrographs of wound scratch assays for untreated control cells (A) and cells treated with oleuropein (OLE) (B) from NF are shown. Oleuropein desorbed from the NF into the desorption medium over five hours was used to test its effect on cell migration. For this reason, the wound scratch assay was performed by scratching a straight line with a thickness of $800 \mu \mathrm{m}$. The closure of this cell-free zone was observed under an inverted phase contrast microscope after 24 hours. As seen in Figure 12, oleuropein (ole) from NF enhanced the cell migration and the width of the cell-free zone decreased significantly after 24 hours compared with untreated control cells (Figure 12). The average cell-free widths of the scratched line after a 24-hour incubation period for untreated control cells (A) and cells treated with ole (B) from NF are shown in Figure 12. The initial cell-free width of $800 \mu \mathrm{m}$ decreased to 300 and $150 \mu \mathrm{m}$ for untreated control cells (A) and cells treated with ole, respectively, as a result of cell migration.

These results have shown that this type of novel nanofibers with adsorbed natural compounds could potentially be used in wound healing materials, provided that they exhibit effective adsorption/desorption of the bioactive compounds effectively as in the case of the silk fibroin nanofibers in the present study.

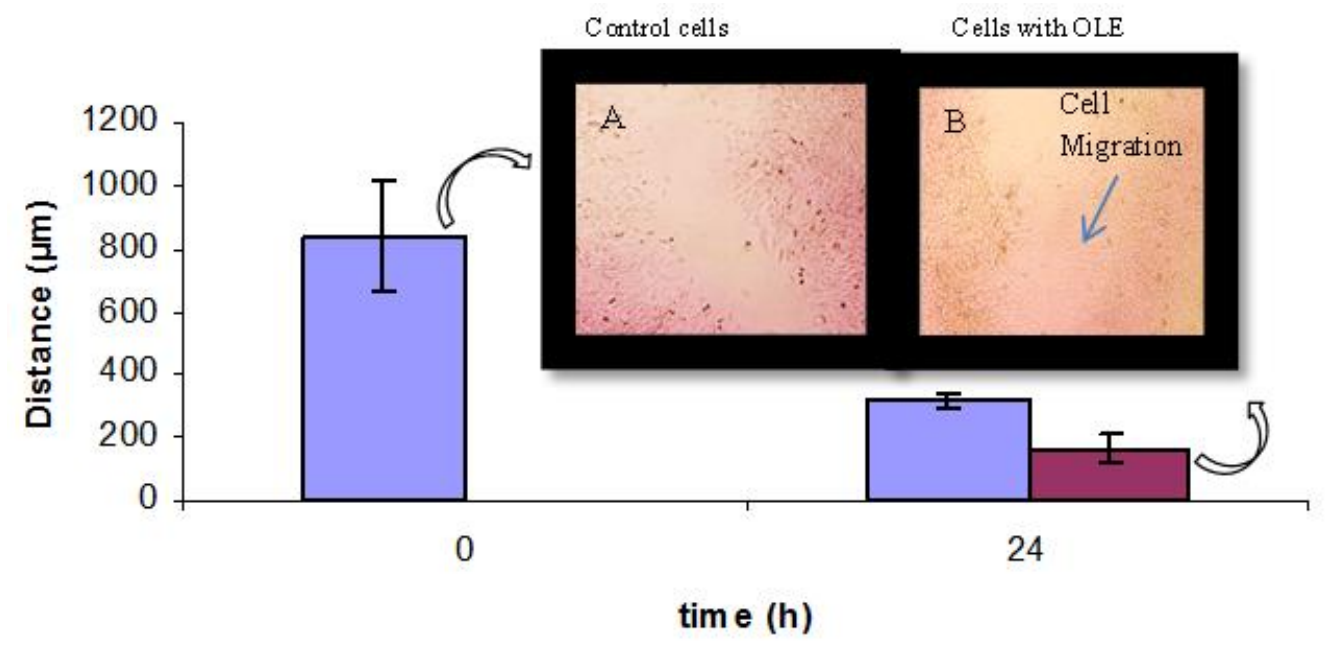

$\square$ Control cells $\square$ Cells with OLE

Fig. 12. Micrographs of wound scratch assays and average widths of the cell-free scratched line after 24 hours of incubation. Untreated control cells (A) and cells treated with oleuropein (OLE) (B) from silk fibroin nanofibers (NF). 


\section{CONCLUSIONS}

Different forms of silk fibroin materials including MF, RSF and NF were successfully prepared by degumming, freeze drying and electrospinning, respectively. All of these silk fibroin materials effectively adsorbed and desorbed oleuropein, which is the major compound with antioxidant and antimicrobial properties present in olive leaf extracts. The silk fibroin nanofibers were found to be much better at the adsorption and desorption of oleuropein when compared with MF and RSF.

Nanofibers can be used in many industrial applications. Applications in the field of medical textiles will become more attractive in the future. In conclusion, as in the present case of oleuropein, natural compounds can be loaded into silk fibroin based nanofibers, which are a good candidate for the development of novel biofunctional medical textiles.

Acknowledgements. The support (DUA01/2010) from Natural Products Research Development Unit (NPRDU) 1ocated in Technology Development Zone for the thesis study of Mr. Ali Bora Balta is gratefully acknowledged.

\section{REFERENCES}

[1] S. S. Silva, D. Maniglio, A. Motta, J. F. Mano, R. L. Reis, C. Migliaresi, Genipin-modified silk-fibroin nanometric nets, Macromol. Biosci. 8, 766-774 (2008). [https://doi.org/10.1002/mabi.200700300]

[2] A. M. Jordan, V. Viswanath, S. E. Kim, J. K. Pokorskia, L. T. J. Korley, Processing and surface modification of polymer nanofibers for biological scaffolds: A review, $J$. Mater. Chem. B 4, 5958-5974 (2016). [https://doi.org/10.1039/C6TB01303A]

[3] C. Burger, B. Hsiao, B. Chu, Nanofibrous materials and their applications, Annual Review of Materials Research 33, 333-368 (2006).

[https://doi.org/10.1146/annurev.matsci.36.011205.123537]

[4] F. Jian, N. Haitao, L. Tong, W. Xungai, Applications of electrospun nanofibers, Chinese Science Bulletin 53, 2265-2286 (2008).

[https://doi.org/10.1007/s11434-008-0319-0]

[5] A. B. Balta, Development of natural compound-loaded nanofibers by electrospinning, MS Thesis, İzmir Institute of Technology (2010). http://openaccess.iyte.edu.tr:8080/bitstream/handle/1114 7/3750/T000216.pdf?sequence $=1$ \&isAllowed=y]

[6] G. Dogan, G. Basal, O. Bayraktar, F. Ozyildiz, A. Uzel, I. Erdogan, Bioactive sheath/core nanofibers containing olive leaf extract, Microsc. Res. Techniq. 79, 38-49 (2016). [https://doi.org/10.1002/jemt.22603]

[7] I. Erdogan, M. Demir, O. Bayraktar, Olive leaf extract as a crosslinking agent for the preparation of electrospun zein fibers, J. Appl. Polym. Sci. 132, 41338-41347 (2015). [https://doi.org/10.1002/app.41338]
[8] K. Bailey, Potential applications of silk fibroin as a biomaterial, Thesis, Ontario, Canada: University of Waterloo (2013).

[https://uwspace.uwaterloo.ca/bitstream/handle/10012/7 621/Bailey_Kevin.pdf?sequence=1]

[9] G. Liu, X. Huang, Y. Wang, Y. Zhang, X. Wang, Thermal transport in single silkworm silks and the behavior under stretching, Soft Matter. 8, 9792-9799 (2012). [https://doi.org/10.1039/C2SM26146D]

[10] A. Nagano, H. Sato, Y. Tanioka, Y. Nakazawa, D. Knight, T. Asakura, Characterization of a Ca bindingamphipathic silk-like protein and peptide with the sequence $(\mathrm{Glu})_{8}(\text { Ala-Gly-Ser-Gly-Ala-Gly })_{4}$ with potential for bone repair, Soft Matter. 8, 741-748 (2012). [https://doi.org/10.1039/C1SM06646C]

[11] Y. Zhang, T. Jiang, Y. Zheng, P. Zhou, Interference of EGCG on the Zn(II)-induced conformational transition of silk fibroin as a model protein related to neurodegenerative diseases, Soft Matter. 8, 5543-5549 (2012). [https://doi.org/10.1039/C2SM25099C]

[12] L. Yu, Y. Feng, Q. Li, X. Hao, W. Liu, W. Zhou, C. Shi, X. Ren, W. Zhang, PLGA/SF blend scaffolds modified with plasmid complexes for enhancing proliferation of endothelial cells, React. Funct. Polym. 91-92, 19-27 (2015). [https://doi.org/10.1016/j.reactfunctpolym.2015.04.003]

[13] F. Galeotti, A. Andicsova, S. Yunus, C. Botta, Precise surface patterning of silk fibroin films by breath figures, Soft Matter. 8, 4815-4821 (2012). [https://doi.org/10.1039/C2SM25089F]

[14] T. Yucel, M. L. Lovett, D. L. Kaplan, Silk-based biomaterials for sustained drug delivery, J. Control. Release 190, 381-397 (2014).

[https://doi.org/10.1016/j.jconrel.2014.05.059]

[15] E. Wenk, H. P. Merkle, L. Meinel, Silk fibroin as a vehicle for drug delivery applications, J. Control. Release 150, 128-141 (2011).

[https://doi.org/10.1016/j.jconrel.2010.11.007]

[16] W. K. Son, J. H. Youk, W. H. Park, Antimicrobial cellulose acetate nanofibers containing silver nanoparticles, Carbohydr. Polym. 65, 430-434 (2006). [https://doi.org/10.1016/j.carbpol.2006.01.037]

[17] J. An, H. Zhang, J. Zhang, Y. Zhao, X. Yuan, Preparation and antibacterial activity of electrospun chitosan/poly (ethyleneoxide) membranes containing silver nanoparticles, Colloid. Polym. Sci. 287, 1425-1434 (2009). [https://doi.org/10.1007/s00396-009-2108-y]

[18] H. S. Mason, H. Warzecha, T. Mor, J. Arntzen, Edible plant vaccines: applications for prophylactic and therapeutic molecular medicine, Trends Mol. Med. 8, 324-329 (2002).

[https://doi.org/10.1016/S1471-4914 (02)02360-2]

[19] J. Sun, Y. Chu, X. Wu, R. H. Liu, Antioxidant and antiproliferative activities of common fruits, J. Agric. Food Chem. 50, 7449-7454 (2002). [https://doi.org/10.1021/jf0207530]

[20] A. N. Sudjana, C. D’Orazio, V. Ryan, N. Ng. J. Rasool, N. Islam, T. V. Riley, K. A. Hammer, Antimicrobial activity of commercial olea europaea (olive) leaf extract, Int. J. Antimicrob. Agents 33, 461-463 (2008). [https://doi.org/10.1016/j.ijantimicag.2008.10.026] 
[21] C. Chen, C. Chuanbao, M. Xilan, T. Yin, Z. Hesun, Preparation of non-woven mats from all-aqueous silk fibroin solution with electrospinning method, Polymer 47, 6322-6327 (2006). [https://doi.org/10.1016/j.polymer.2006.07.009]

[22] K. H. Kim, L. Jeong, H. N. Park, S. Y. Shin, W. H. Park, S. C. Lee, T. I. Kim, Y. J. Park, Y. J. Seol, Y. M. Lee, Y. Ku, I. C. Rhyu, S. B. Han, C. P. Chung, Biological efficacy of silk fibroin nanofiber membranes for guided bone regeneration, J Biotech. 120, 327-339 (2005). [https://doi.org/10.1016/j.jbiotec.2005.06.033]

[23] S. Li, H. Wu, X. D. Hu, C.Q. Tu, F. X. Pei, G. L. Wang, W. Lin, H. S. Fan, Preparation of electrospun PLGA-silk fibroin nanofibersbased nerve conduits and evaluation in vivo, Artif. Cells Blood Substitut. Biotechnol. 40, 171178 (2012).

[https://doi.org/10.3109/10731199.2011.637927]

[24] Q. Wang, J. Xiong, H. Zhang, N. Li, J. Xie, G. Liu, Preparation and properties of PBS-SF core-shell composite ultrafine fibrous membranes by coaxial electrospinning, J Acta Materiea Compositae Sinica 28, 88-93 (2011).

[25] Y. Hang, Y. Zhang, Y. Jin, H. Shao, X. Hu, Preparation of regenerated silk fibroin/silk sericin fibers by coaxial electrospinning, Int. J. Biol. Macromol. 51, 980-986 (2012). [https://doi.org/10.1016/j.ijbiomac.2012.08.010]

[26] S. Shao, L. Li, G. Yang, J. Li, C. Luo, T. Gong, S. Zhou, Controlled green tea polyphenols release from electro- spun PCL/MWCNTs composite nanofibers, Int. J. Pharma. 421, 310-320 (2011).

[https://doi.org/10.1016/j.ijpharm.2011.09.033]

[27] G. Jin , M. P. Prabhakaran, D. Kai, S. K. Annamalai, K. D. Arunachalam, S. Ramakrishna, Tissue engineered plant extracts as nanofibrous wound dressing, Biomaterials 34, 724-734 (2013).

[https://doi.org/10.1016/j.biomaterials.2012.10.026]

[28] E. Altiok, D. Baycin, O. Bayraktar, S. Ulku, Isolation of polyphenols from the extracts of olive leaves (olea europaea 1.) by adsorption on silk fibroin, Sep. Pur. Tech. 62, 342-248 (2008).

[https://doi.org/10.1016/j.seppur.2008.01.022]

[29] D. Baycin, E. Altiok, S. Ulku, O. Bayraktar, Adsorption of olive leaf (olea europaea 1.) antioxidants on silk fibroin, J. Agric. Food Chem. 55, 1127-1236 (2007). [https://doi.org/10.1021/jf062829o]

[30] Ö. Malay, O. Bayraktar, A. Batıün, Complex coacervationof silk fibroin and hyaluronic acid, Int. $J$. Biol. Macromol. 40, 387-393 (2007).

[https://doi.org/10.1016/j.ijbiomac.2006.09.017]

[31] H. Fong, I. Chun, D. H. Reneker, Beaded nanofibers formed during electrospinning, Polymer 40, 4585-4592 (1999). [https://doi.org/10.1016/S0032-3861 (99)00068-3]

[32] A. Sohrabi, P. M. Shaibani, T. Thundat, The Effect of applied electric field on the diameter and size distribution of electrospun nylon6 nanofibers, Scanning 35, 183-188 (2013). [https://doi.org/10.1002/sca.21044] 
